James Tar Tsaaior

James Tar Tsaaior teaches at PanAfrican University, Lagos, Nigeria. His research interests include African and Afro-Diasporic Literatures, Folklore, Gender and Cultural Studies as well as Literary Theory and Criticism.

E-mail: tsaaiortar@yahoo.com

\section{Exile, exilic consciousness and the poetic imagination in Tanure Ojaide's poetry}

\title{
Exile, exilic consciousness and the poetic imagination in Tanure Ojaide's poetry
}

As a thematic trajectory, exile constitutes a visible presence in the Nigerian poetic afflatus and imagination. This is sometimes not adequately or sufficiently acknowledged. Increasingly, however, exile and exilic consciousness have continued to occupy a contested and contestable site in literature especially Nigerian poetry. This is essentially because of the multiple and shifting networks of significations that undergird the very constitution and definition of home, exile and the exiled. While exile could signify absence from one's homeland and hence register an erasure of physical presence from a particular landscape, other interpretive grids that negotiate exile refract it as a spiritual and psychological state that does not necessarily translate to physical absence from home. The essay contends that both modes of epistemology and hermeneutic insights are tenable. Its framing and defining concern is the negotiation of the theme of exile in Nigerian poetry especially the poetry of Tanure Ojaide. The paper's sustained argument is that Ojaide's poetic imagination and sensibility have generously benefited from the trope of exile which has been conditioned by the reality of living and working away from home in the United States of America even as the poet himself problematises this reality with his frequent visits home and the construction of a hybrid identity as a cosmopolitan citizen of the world. The paper uses Ojaide's When It No Longer Matters Where You Live as a paradigm of textual representation to underscore the exilic consciousness in Nigerian poetry. It concludes that Ojaide's volume contributes significantly to the work on the theme of exile in world literature and reflexively foregrounds the currency of the theme of exile in Nigerian poetry and, indeed, literature. Key words: exilic consciousness; Nigerian poetry; poetic imagination; Tanure 0jaide.

"[E]xile is no longer perceived as a banishment or expulsion from one's homeland but rather a condition commonly shared by a network of writers." (Shaw 2006: 24).

"[T]he great strength of modern writing in English lies much more in its exiles than in its metropolitan writers [...] the reason lies partly in the stronger sense of home which the exile has, and in the clearer sense of his identity which his home gives him."

(Gurr 1998: 9). 
"When it no longer Matters is an intense dialogue with the self-negotiating the post-modern conditions associated with exile. In it, Ojaide reaches deep into the world that he has lived and hoped for; he goes headlong into strange misadventures to understand the meaning of living outside home, concluding that it really does not matter anymore where one lives. Dictatorship, social insecurity, corruption, political ineptitude and cultural insensitivity in the poet's homeland have all conspired against him. And the result is this decision. He is not alone." (Okome 2002: 15).

\section{Introduction}

In his collection of critical essays significantly titled Home and Exile, world-renowned Nigerian novelist and Africa's foremost storyteller, Chinua Achebe (2000: 2), establishes the intersection between home and exile as composites that negotiate the human existential condition. In Achebe's critical practice and literary sensibility, home and exile are, as such, coextensive as they share a curious kindredship, which is sometimes ignored or not always sufficiently acknowledged and appreciated. This compositeness of home and exile is amply demonstrated in Achebe's life as a writer and critic who, like Tanure Ojaide, is in patriotic love with his native homeland, Nigeria, but who now lives in exile in the United States of America. It is, therefore, not an exaggerated or extravagant claim to postulate that every writer, in some fundamental sense, is an exile. This assertion finds validation in the dual status of the writer whose personhood is simultaneously situated within the limits of society and outside of it.

Against this important backdrop, it is safe to state that by the very nature of their vocation, writers inscribe their distinct individualities and existential experiences within the fabrics of their writings as veritable members of their societies. In strict fidelity to the protocols of their trade, writers live above society, outside of it; a kind of self-imposed exile, while at the same time remaining part of it, as a function of the compulsion to objectively focus on society in its motions in the historical continuum. They do so by intervening in the tapestry of societal events in the ceaseless flow of its currents, interpreting its moods and temperaments, defining its present, and divining its future of (im)possibilities. In this perspective, writers are exiles not in the strict sense of physical (dis)location or (dis)placement from the homeland but rather, in the psycho-social and spiritual dimensions of their existence and in consonance with the demands of their sacred office.

Exile and exilic consciousness can operate at two broad existential grids. These are the internal and the external. Internally, one can be an exile while rooted in one 
particular place in one's homeland without physical displacement. This is spiritual exile which registers itself in terms of absence through presence. Internally too, one can be within the borders of a nation-state but may be dislocated from one's immediate local milieu. Then, there is the external exile, which represents itself in physical flight from one's homeland in a particular nation-state to another outside of one's native country. These modes of exile and exilic consciousness are precipitated by the contingencies of state political repression, economic recession, religious strife, labour migration, racial discrimination and cultural practices, among others. As Roger Bromley (2008: 28) corroborates, "Conflict, violence and rights abuses might drive people out of their countries of origin, but economic deprivation, lack of opportunity, and the desire for better life are also powerful motivating factors."

These contingencies which are intrinsic to the ideological state apparatuses prescribe, legislate, regulate, impose and enforce particularistic behavioural patterns which individuals, including writers, must conform to (Althusser 1972: 141-42). Nonconformity often spells victimhood for writers. This is especially when they are engaged in confrontation with the state in speaking back to power as a way of fulfilling the sacred mandate of their vocation as prophets, vates, seers, conscience of society and as upholders of the truth, justice and equity. This has made some writers exiles in their very homeland. It has also compelled the flight of some writers from the home environment as they are erased from its contours because of the hostility to more hospitable and accommodating spaces. As Kubayanda (1990:5) notes, "Postcolonial dictatorship in Africa concerns itself with repression, which in effect means the arrest, exile, execution, or consistent harassment of dissident voices. The general result of dictatorship is an atmosphere of fear, hate and humiliation."

\section{Ojaide and the trope of exile in When It No Longer Matters Where You Live}

Within the discursive space and critical practice, which define postcolonial and postmodern studies, the reality of exile almost always invokes the homeland as an oppositional binary. This invariably constructs mutually exclusive or dichotomous relations between exile and homeland such that the two are refracted as antinomies. In When It No Longer Matters Where You Live Ojaide radically conflates these two concepts and invests them with synonymous significations thus divesting them of their essential exclusivity. To Ojaide, it no longer matters where one lives because wherever one finds oneself is home provided the place is conducive to one's existence and fulfilment in life. In contradistinction, home is not really home if it is hostile; if it compromises one's aspirations and does not provide opportunities for one's happiness and self-actualisation. In this regard, "Home for the exile is where safety lies" (Mowah 2002: 40). This makes home and exile relative existential states and delineates them as sharing only a thin line of distinction between them. 
Ojaide's title, however, contradicts and deconstructs its claims and assumptions from within. This is because it really does matter where one lives and this explains why there are still exiles. From the title, Ojaide problematises the idea of home and exile: the two are no longer (un)desirable conditions simply because one is a physical or spiritual rootedness in a particular topos and the other an erasure or escape from it to a space which is congenial and inviting. This is even as the latter evokes nostalgic memories of "home" and a real longing for a return to it. In the main, the poet raises the spectre of the problematic that the conditions which necessitate exile are present everywhere though in varying degrees or dimensions of intensity. In this regard, while some are escaping a particular milieu into exile in another place, others are moving into the same place just vacated. It, therefore, no longer matters where one lives; but it also matters because it is for that very reason that exile is still part of the human condition.

But it will also signify that through this volume, the poet is subtly inviting us to a celebration of globalisation. As a new world order, globalisation celebrates the dissolution of traditional boundaries in the areas of geography, travel, culture, entertainment, etc. through the instrumentality of digital and satellite technological devices like television, video, cellphone, Internet, air transportation, among others. These have immensely facilitated communication and the mass movement of peoples across diverse spaces within a short period of time. It, therefore, does not matter where one lives because communication and travel have ceased to be difficult and tasking problems confronting humanity. Indeed, we now belong to a borderless global neighbourhood which keeps shrinking interminably. This has continued to define our world in terms of postnationality and transterritoriality, a reality which writers who have experienced life as exiles in diverse territorial spaces have become mongrelised to the point of becoming cultural hybrids and cosmopolitan citizens of the world (Said 2000: xxviii).

In this cultural schema, "to forget that there is a world we belong, to confine ourselves within narrowly defined cultural frontiers, would [...] be to go voluntarily into the form of internal exile" (Rushdie 1992: 17). This has forged a multicultural ensemble where cultural essentialism has become fossilised with a hybrid and plural cultural heritage which is negotiated and renegotiated in a fluid and continuously changing cultural space in a postmodern world ethos. It has also influenced in a considerable manner the writing in the present world of postmodernity. As Dharwadker (1996: 62) argues, it affects the process of writing itself, makes the influences on a particular writer or text varied, widespread, rapid and unpredictable: alters the intended and perceived qualities of a literary work; and complicates the contexts in which an author or a work can be placed and understood.

As a result of this variegated cultural experience, postcolonial African writers have laid claim to this postmodern moment of hybridity in the articulation of their 
concerns whether they are at home or in exile (diaspora). They, therefore, perceive themselves as heirs to a cultural multivalence, which must be mobilised in the galvanization of their creative energies. According to one critic whose comment is relevant to Ojaide in his poetic concern with exile and exilic consciousness, "Many African writers on the continent and in the Diaspora have taken artistic advantage of the presence of hybridity in post-colonial culture. There is even a rich legacy of work written by blacks about living or traveling in the West, reflections on their experiences of racism and alienation and sometimes even joy." (Specht 2006: 50).

In commenting on the Indian exilic condition, Salman Rushdie notes the impossibility of the writer who is an exile, emigrant or expatriate to reclaim that sense of innocence or idyll associated with the homeland which has been lost as a result of exile and alienation from home. To Rushdie (1992: 10) what is incumbent on the exile to do is to create a homeland of the mind, an imaginary locale which will approximate the real home as its reclamation in tangible terms is not possible. As he puts it,

It may be that writers in my position, exiles, emigrants or expatriates, are haunted by some sense of loss, some urge to reclaim, to look back, even at the risk of being mutated into pillars of salt. But if we look back, we must also do so in the knowledge - which gives rise to profound uncertainties - that our physical alienation from India inevitably means that we will not be capable of reclaiming precisely the thing that was lost; that we will, in short, create fictions, not actual cities or villages, but invisible ones, imaginary homelands, Indians of the mind.

It is this postmodern refraction of home and nationhood as a construction of the mind that structures the idea of nationhood as an "imagined community" (Anderson 1991).

Ojaide's poetic engagement in When It No Longer Matters Where You Live embeds Rushdie's argument but also negates it. For instance, the impact of his physical separation from Nigeria, his homeland, is limited by his frequent visits and cultural renewal and recuperation. In this regard, it is difficult to conclude with magisterial certitude that he is haunted by an acute sense of loss which calls for an elaborate programme of cultural reclamation and retrieval through the creation of fictions and imaginary homelands of the mind. Indeed, as some scholars now contend, "Contemporary exilic discourse has in the main, been supportive of the globalization phenomenon rather that the reclaiming of lost/past glories" (Oripeloye 2008: 5). So even when he does not execute a physical homecoming, Ojaide is frequently informed and hence knowledgeable about events at home through his poetic creation of a "faithful birdfriend". In "I am still the Iroko", the poet deploys this avian metaphor of the reliable gatherer of news from and about home for him, his poet-friend far away in the United States. As he states: 


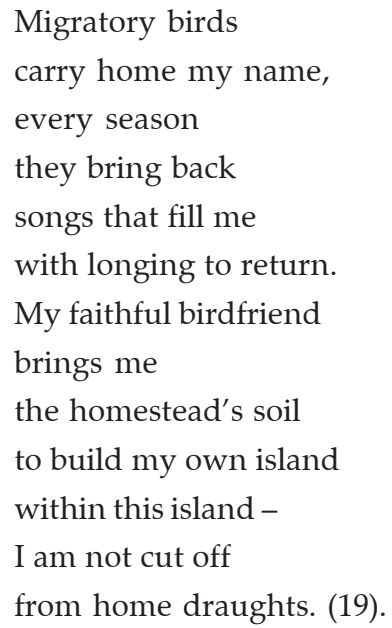

Even though the poet's sense of physical alienation is minimised by his birdfriend who feeds him with valuable information about home-something reminiscent of the biblical Noah and the dove after the Deluge and Prophet Elijah and the raven at the Brook of Cherith - Ojaide is assailed by nostalgic feelings and memories about home which provoke a longing for a return journey home. In this perspective there is an affirmation of the Rushdean avowal concerning the exile being haunted by a sense of loss and a longing for home. The symbolic image of migratory birds as dependable companions and veritable sources of information is also hinted at in "The course of waters" where

Waters have carried my boat wherever they had their way, which is everywhere on earth. My course ran through clear and dark rivers - I recognized signs of imminent downpours, and none drowned me...

Migrant birds kept me company and broke the chill - . (12).

In a way, there is a sense of ambiguity and ambivalence in Ojaide's poetic mind regarding the construction of the epistemological boundaries between home and exile. He seems to radically remap their borders and in the process reconstructs them as complementarities. This detracts from their refraction as Manichean entities. The reterritorialisation configures home and exile as mutually inclusive and as sharing an interface without necessarily compromising each other. In Ojaide's poetic imagination, therefore, home is exile and exile home hence it no longer matters where you live. This hermeneutic idea about home and exile is validated in his poetry through the 
convergence of the local and the global which results in a 'glocal' consciousness: this is a visible trajectory in the present volume. In "I am still the Iroko", the poet resorts to the appropriate botanical metaphor of the iroko, a topographic and cultural marker of his Niger Delta homeland for the framing of poetic significations. The iroko is quintessential of Ojaide's poetry as his maiden collection is significantly entitled Children of the Iroko (1973). The iroko is a strong and powerful tree, which serves as a symbolic image of solidity and rootedness in his cultural ontology, deep grounding in sacred tradition and the passion for their longevity and continued efflorescence.

On the other hand, the ambivalence concerning home and exile inheres in the image of 'transplant'. This is an agrarian or biological metaphor which represents the raising or tending of a plant or tree and transferring from the nursery, its natural habitat, to a different environment where it is planted in another soil, or grafted to another tree for a new life. This is also true of human parts that are transplanted. The poet's nuanced argument is that he is simultaneously at home and in exile, at home abroad, by being a local and global citizen. In "Colour me", the poet celebrates a common humanity united by a humane and humanistic vision which is galvanized by the sameness of a noble human culture and civilization which de-emphasises colour difference and racial configurations. As the poet envisions, the United Nations Organization that was founded for this objective should be in the vanguard of promoting the ideal of one humanity despite the racial and cultural differences that have been erected over time. This is what Ahmad (1992: 119) calls that "civic ethos, that moral bond with each other, without which human community is impossible."

The sense of ambivalence endures in "Accents", invoking Rushdie's proclamation of the difficulty of the project of reclamation of the past by the exile except through memories. As Ojaide himself avows: "Memories of festival music/relax my muscles" (17) and help in the recovery process of an acute sense of loss. This sense of loss is underscored by the poet through the formulaic refrain: "I have left behind" with repeated urgency and immediacy, highlighting a heightened nostalgic feeling ending climactically in "I have left behind / a delta of fortune" (18). The fixation with home as an ideal spatial location and as a repository of the longed for and sought after by the exile through memory and re-memory provokes critical interrogation as to what precipitates exile and makes it desirable. In other words, why is exile an attractive option even as it is fraught with tensions, fears, anxieties and an overarching attachment to home that was an object of abandonment in the first place?

The answer to this question partly lies in what can be said to be the push factors and the pull realities: the tensions and fears and anxieties that are present at home and the promise of a better quality of life that exists elsewhere. Ojaide, for instance, provides an insight into what drives people into exile in the metaphor of the soil and flowers in "Home ground". The soil here refers to the homeland, Nigeria, where dreams dutifully nursed are turned into nightmares, hopes energetically expressed 
evaporate into thin air and the national patrimony is appropriated by a tiny coterie of greedy politicians. The flowers are promising citizens who are caught in this inextricable web spun by an irresponsible, decadent and exploitative leadership and are not allowed to bloom and to fruit, stunting their growth and destinies. This is precisely what happens to Veronica and Angie, two promising students of the poet's who have been frustrated through early marriages and their future compromised by patriarchal hegemony and sociocultural ideologies which are hostile to womanhood in a phallocentric society. Appropriating Nobel laureate, Toni Morrison's felicitous expression that this soil is not good for some flowers, the poet states:

Not good for hibiscus, not good for crocus

Nor for female-scented bougainvillea,

this soil is bad for some flowers...

look at veronica once so self-assured

that I called her a general - that was long before

being harried into a family-made bed of marriage.

She came back to campus weeping, stripped of colour

\& I knew the nursery bed killed the flower before it bloomed.

And angie, so spritely that I divined that she would fly

so high in the sky, forever pushing the horizon farther...

But after fifteen years she managed to slip out a note

from the male-guarded persecution house: "I used to

dream before but now I don't dare anymore..."

The land thwarts her flowers crying for redemption. (31-32).

Inevitably, the poet concludes "hence many flourish out of home ground, transplanted / because the native soil is bad for their bright kind" (32). Although this presents an idealist picture of exile, it nevertheless validates the option of exile for many.

What has happened to Veronica and Angie represents phallocentric politics in the domestic domain but Ojaide turns his poetic lens to the arena of diverse public spheres. Here, he wields an angry, accusatory and transgressive voice laced with poetic venom, deploring the repressive and oppressive social, economic and political structures constructed by a postcolonial nation-state in a perpetual state of becoming which reduces the majority of its people to mere vermin. In "Libation", the poet again identifies what necessitates exile. Latching on the metaphor of bees, "the bees of Abuja" (39), Abuja being Nigeria's capital city and a symbol of national opulence but also public malfeasance as well as material and moral squalor, these bees "wreak havoc on the public/ without benefit of enjoying their draughts" (39). In a bilious and caustic poetic language, Ojaide refers to the politicians who have imposed themselves on the people as vultures and hawks, predatory birds that portend only death for their preys who in this situation are the mass of the marginalised people. 
Nigeria in this sense is refracted by the poet as an elephant - referring to her selfcharacterisation as the giant of Africa, a somnolent one though - because of her sheer immensity of geography and prodigious endowments in human and material resources. The fate of this elephant, to the poet, hangs in the balance because "One leg lost in the deeps, the other hanging to land" (40) is a precarious state which the nation has wilfully driven itself into. This quotidian condition threatens the very future survival of the nation and stunts her growth as "one forward step, then a backward leap / confines us to an antiquated millennium" (41). The theme of exile and the complex of circumstances that propel it in the postcolonial state are further pursued in "Dateline Abuja" and the sequence of poems titled "Home song" which are movements of songs that navigate the beleaguered Nigerian condition wracked by naked thievery, unbridled dictatorship, institutionalised corruption, perpetual inertia in public life, and a precipitous descent in the quality of life. In this movement of songs, as in the entire volume, Ojaide distils a jeremiad symphony of songs whose tapestry function as a sad and unrelieved commentary on not how to invent nationhood, deploring the leadership for its perfidy and the led for its active collaboration and stunning silence in the face of naked treachery and brutal violation.

In all these, it in the title poem, "When it no longer matters where you live", that the trajectory of exile is most clearly articulated, though not without the accompanying valorisation of ambivalence. Even as the poet avows that it no longer matters where you live, exile remains a vexed issue in his poetic consciousness and sensibility. Exile represents the last resort, an inevitable decision borne out of compulsion by a variety of chequered circumstances prevalent at home. According to Okome (2002: 15),

Exile now seems a permanent option. It is inevitable. Ojaide, the patriot and poet, is slowly slipping into that world [...] a world which Ojaide had always found incongruous to his poetic vocation. Although he still cries for home, something inside reveals that he now knows "what it is to lose our home". All too suddenly, we begin to notice dents on the map of the homeland that Ojaide has jealously upheld. Another kind of home is fast forming and new ideologies of life and poetic styles are forcing him to capitulate. This is the profound meaning that Ojaide's $[\ldots]$ When It No Longer Matters Where You Live, a truly post-modern response to exile elicits...

But transcendent to this, Ojaide's concern in the volume is not an individuated, privatist brooding about exile as he boldly assumes the responsibility of the public poet with a communal voice and conscience, an office which demands courage and selfless abandonment for the public good. Rhetorically, he interrogates the hegemonic structures and decadent ideologies that precipitate exile. However, at the same time he enters an argument which implicates exile as a cowardly act that offends and betrays "martyred ones" who have paid the supreme price in the defence of freedom and the rights of the commonwealth with their lives. In unmistakable poetic strokes, the poet drives home the message when he avows that the "home" abroad, no matter 
its ostensible safety, remains a long night(mare) from which the exile impatiently struggles and awaits the arrival of dawn:

Except by returning to libate the soil

With the Cock of Abuja's blood,

Will exile not offend martyred ones?

For all its refuge, the foreign home

Remains a night whose dawn

I wish arrives before its time. (77).

As the poet continues to lament, the pain that the exile experiences in other lands is no less grievous than the one at home as the conditions that precipitate exile are concomitant with living abroad without attenuation. He states:

There's none so hurt at home

who forgets the pain outside -

that's the persistent ache one carries

until home's safe to return to,

when it no longer matters

where you live! (77).

It is, therefore, misleading when exile is sometimes thought to offer an alternative existence which is better than home. As Ojaide indicates, sometimes exile compounds and aggravates the condition of the exile. This is the reality expressed in "Immigrant voice" where the glamorous pictures presented of life abroad soon pale into unrelieved grimness for the exile who now bemoans his forlorn fate and curses the day he took the decision to abandon life at home for another in a foreign land. Rendered in pidgin, which is an accessible idiom, the poem is linguistically representative of low educated people who participate in immigration programmes like the American lottery. These are forced into exile by lean circumstances at home only to realize that they do not have the requisite education and social status as exiles to stand the competition abroad. The poet-persona self-reflexively and dispassionately looks at life in America:

The picture of here from home is different

from the wilderness I de see night and day.

This na America with homeless for every corner

that I think I de a numberless world?

Where all de fine fine things in that picture:

everybody dress that I think

na angels, Hollywood Heaven they misspell?

Now I work standing so te for minimum wage,

get dollars for one hand and give them out for another.

I come back from work so dead I can't eat or sleep

and before dawn I don get up to begin another slave day. (105). 
This sordid picture Ojaide delineates of exile is synonymous with the one the exile thought he had escaped from home. Sadly, it is like jumping from the frying pan into the fire as his precarious life becomes a conundrum and an unrelieved nightmare he cannot wake from. The commodified and consumerist lifestyle associated with America's late capitalist tendencies, the brutal exploitation of the weak by the strong and the hierarchical social and economic structures, which define the American landscape all in the name of an elusive freedom, now clearly dawn on the poetpersona. He now sees America in its true nakedness as "photo-trick", "mirage" full of sophisticated criminality, violence, racial discrimination, poverty, social morass and cultural stasis.

\section{Conclusion}

When It No Longer Matters Where You Live represents a multicultural discursive engagement with a post-modern world, which is at once local and global, particularistic and universalistic, in its moods and temperaments, identical differences and different identities. It is a discourse that structures our sense of homeland and exile and coalesces these two modes of existence as quintessential of the human condition. In this regard, the volume accomplishes its framing and governing concern which is to negotiate exile as an existential reality. Whether it is internal or external, Ojaide demonstrates that exile, though desirable at certain crucial moments, is not absolute but has its limitations in giving the exile the full range of life's options, possibilities and fulfilment. The mere contemplation of exile necessarily suggests alienation from home and the concomitant sense of loss and displacement that follows, triggering off the longing for an 'ideal' place called home. Ojaide resolves the tension between the two through their fusion.

Through this volume, the poet enters the exilic discourse framing it within the schema of a global consciousness which celebrates cultural hybridity and "double consciousness" (Gilroy 1995: 1). It is this reality of exile as a veritable phenomenon for the construction and re-construction of cultural identity within a globalised space which emphasizes the intensification of a unified consciousness that appeals to Ojaide as a writer. This perspective is in harmony with the episteme that has gained currency within exilic and diasporic discourse that "the experience of migrant or diasporic people is central to contemporary societies" (Gillespie 1995: 3). Ojaide participates in this discourse as a writer who has appropriated what the new world offers: the tropes, imagery, symbols, and themes which are consistent with exile in a global environment. What is, however, remarkable about him is that Ojaide is deeply moored in and conversant with his cultural roots and ontology such that in his poetic imagination and sensibility, home and exile have ceased to be binaries as he has fused them into a collective, composite experience. 
It is this plural cultural manifestation that interlaces When It No Longer Matters Where You Live a poetic idiom through which Ojaide distils large statements which negotiate exile in relation to the overarching assumptions of globalization and a new world order where exile and exilic consciousness have become the defining markers of the age. As Ojaide himself affirms, "I do not believe in isolating one culture from others. They should all be seen in a global perspective [...] while culture, environment, history, and society condition the individual poet and his or her writing, the mere fact of writing or articulating in words, feelings or ideas has its parallel manifestations worldwide" (Ohaeto 2003: 99). Thus, Ojaide's poetic imagination is ruled by the reality of exile in a globalised milieu where it does not really matter where you live. Exile is, as such, radically redefined by Ojaide in his poetry in a manner that renders indistinct its boundaries with home which in the Saidian concept approximates a native place. It is this emergent exilic discourse and the globalised consciousness it espouses that Ojaide invites us to participate in.

\section{Works cited}

Achebe, Chinua. 2000. Home and Exile. New York: Anchor Books.

Ahmad, Aijaz. 1992. In Theory: Classes, Nations, Literatures. London: Verso.

Althusser, Louis. 1971. Lenin and Philosophy and Other Essays. London: New Left Books.

Anderson, Benedict. 1991. Imagined Communities. London and New York: Verso.

Bromley, Roger. 2008. Between a world of need and a world of excess: Globalised people, migration and cinematic narrative. In A. Oboe, C. Gualtieri and R. Bromley (eds.). Working and Writing for Tomorrow: Essays in Honour of Itala Vivan. Nottingham: Critical, Cultural and Communications Press, 27-46.

Dharwadker, Vinay.1996. The internationalisation of literature. In Bruce King (ed.). New National and Post-Colonial Literatures: An Introduction. New York: Oxford University Press, 56-77.

Gillespie, Marie. 1995. Television, Ethnicity and Cultural Change. Routledge: London and New York.

Gurr, Andrew. 1998. Writers in Exile. Hemel Hempstead: Harvester Wheatsheaf.

Kubayanda, J. B. 1990. Dictatorship, oppression and the new realism. Research in African Literatures, 21(2): 5-11.

Mowah, Frank Uche. 2002. Spiralling visions and labyrinthine images: Tanure Ojaide's Children of Iroko and Labyrinths of the Delta. In O. Okome (ed.) Writing the Homeland: The Poetry and Politics of Tanure Ojaide. Bayreuth: African Studies Series, 31-50.

Ohaeto, Ezenwa. 2003. Winging Words: Interviews With Nigerian Writers, and Critics. Ibadan: Kraft Books.

Ojaide, Tanure. 1998. When It No Longer Matters Where You Live. Calabar, Nigeria: University of Calabar Press.

Okome, Onookome. 2002. Introduction: Tanure Ojaide: The poet laureate of the Niger Delta. In O. Okome (ed.). Writing the Homeland. Bayreuth: African Studies Series, 1-6.

Oripeloye, Henri. 2008. Globalisation, cultural identity discourse and the emerging configurations in the exilic poetry of Odia Ofeimun and Tanure Ojaide. Seminar Paper, Department of English, University of Ibadan.

Rushdie, Salman. 1992. Imaginary Homelands: Essays and Criticism 1981-1991. London: Granta Books.

Said, Edward. 2000. Reflections on Exile and Other Essays. Cambridge, Massachusetts: Harvard University Press.

Shaw, Kristi. 2006. Re-creating identity in exile: Hybridity and gender in the works of Assia Djebar, Leila Sebar and Malika Mokeddem. Unpublished PhD dissertation, Department of Modern Languages and Classics, University of Alabama.

Specht, Mary Helen. 2006. Contemporary white fiction on Africa: Is there a role for white writers in post-colonial literary resistance? In Ibadan: Journal of English Studies, 3: 40-53. 